\title{
Pelibatan Masyarakat sebagai upaya Pemerintah Kota Bontangdalam Pencegahan Dan Peningkatan Kualitas Perumahan Kumuh Dan Permukiman Kumuh
}

\author{
Muhammad Habibi \\ Dosen Ilmu Administrasi Negara FISIP Universitas Widya Gama Mahakam Samarinda \\ e-mail: habibi.mayangmaurai@gmail.com
}

\begin{abstract}
Abstrak
Penelitian ini membahas pelibatan masyarakat sebagai upaya Pemerintah Kota Bontang dalam Pencegahan Dan Peningkatan Kualitas Perumahan Kumuh Dan Permukiman Kumuh melalui Forum Discussion Group (FGD) masyarakat Kota Bontang, yang diharapkan pada 2019 Kota Bontang akan terbebas dari kumuh dengan ditunjang Gerakan 100-0-100 dari Kemeterian PUPR.Penelitian ini menggunakan pendekatan kualitatif deskriptif.
\end{abstract}

Hasil penelitian menunjukkan, pertama, perwujudan program Kota Tanpa Kumuh di Kota Bontang telah menjadi bagian dan tanggung jawab masyarakat Kota Bontang secara menyeluruh melalui partisipasi yang mendalam dan integratif.Kedua, terdapat sejumlah elemen masyarakat yang memiliki peran besar, diantaranya dari pihak tokoh masyarakat, tokoh agama, tokoh pemuda, akademisi, lembaga dan kelompok swadaya masyarakat, ibu-ibu PKK, dan tentu dari Tim Program KOTAKU Kota Bontang yang telah memberi pengayaan Rancangan Peraturan Daerah Kota Bontang tentang Pencegahan Dan Peningkatan Kualitas Perumahan Kumuh Dan Permukiman Kumuh.

Kata kunci: Partisipasi, Masyarakat, FGD, Kumuh, Kota Bontang.

People Engagement as Bontang Government's Efforts to Prevention and Improvement of the Slums Quality

\author{
Muhammad Habibi \\ Lecturer in Public Administration of Social and Political Science in \\ Widya Gama Mahakam Samarinda University \\ e-mail: habibi.mayangmaurai@gmail.com
}

\begin{abstract}
This study discusses about people engagement as bontang government's efforts to prevention and improvement of the slums quality through the Forum Group Discussion (FGD) of Bontang's people, which is expected that in 2019 Bontang will be free of slums, supported by 100-0-100 action of PUPR ministry. This study used descriptive qualitative approach. The results showed that, first, the embodiment of Cities without Slums Program in Bontang has become part and responsibility of Bontang's people as whole through integrative and deep participation.Second, there are some elements of people in Bontang who have a major role, including on the part of community leaders, religious leaders, youth leaders, academics, institutions and self-help groups, PKK, and the of course the of Team "KOTAKU" Program in Bontang who has given Local Regulation Draft of Bontang City about Prevention and Improvement of the Slums Quality
\end{abstract}

Keywords: Participation, Community, FGD, Slums, Bontang.

Pelibatan Masyarakat sebagai upaya $P$ emerintah Kota Bontang dalam $P$ encegahan

Dan Peningkatan Kualitas Perumahan Kumuh Dan Permukiman Kumuh $\gg>1$ 


\section{Latar Belakang}

Perumahan dan kawasan permukiman merupakan sumber daya milik bersama/publik (common pool resources) yang tanpa dikelola secara efektif dan efisien, serta dijaga dengan baik dipastikan dapat menimbulkan tragedi sumber daya umum (tragedy of common). Untuk itu perlu pengintegrasian penggunaan dan pemanfaatan perumahan dan kawasan permukiman sebagai pusat permukiman masyarakat baik di kawasan perkotaan maupun di kawasan perdesaan, baik di kota megapolitan, metropolitan, kota besar, kota menengah dan kota kecil serta kota perdesaan yang terus berkembang. Perumahan dan kawasan permukiman sebagai pusat permukiman juga pusat perekonomian, pusat sosial dan budaya. Penggunaan dan pemanfaatan perkotaan sebagai sumber daya publik untuk dapat di gunakan dan dimanfaatkan sebesar-besarnya untuk kepentingan publik.

Perkembangan Kota Bontang yang dinamis membawa pengaruh bagi perkembangan kehidupan masyarakat kota itu sendiri. Perkembangan ini menjadi daya tarik bagi masyarakat yang dapat mempengaruhi tingginya arus tenaga kerja baik dari dalam kota itu sendiri maupun dari luar wilayah Kota Bontang.

Peningkatan jumlah penduduk berpotensi menjadikan Kota Bontang semakin padat dan kumuh serta dapat menjadikan kawasan permukiman yang berfungsi sebagai lingkungan hunian menjadi semakin tidak layak huni. Kondisi perumahan dan kawasan permukiman yangg tidak layak huni berpotensi menurunkan kualitas hidup, menghambat perkembangan dan pertumbuhan masyarakat.

Bagi Kota Bontang yang termasuk kedalam klasifikasi kota menengah atau sedang, menjadi salah satu kota pelaksana pilot project Program Kota Tanpa Kumuh (KoTaKu) dari Kementerian Pekerjaan Umum dan Perumahan Rakyat merupakan sebuah kepercayaan dan tantangan tersendiri.Mengingat Kota Bontang baru saja melaksanakan suksesi kepemimpinan baru untuk periode 2016-2021 ditengah defisit anggaran yang menimpa hampir seluruh wilayah Kabupaten/Kota dan Provinsi di Indonesia, tidak terkecuali Kota Bontang. Kondisi tersebut menyebabkan pemerintah Kota Bontang harus lebih memaksimalkan potensi sumber daya yang ada di wilayah Kota Bontang, termasuk potensi yang dimiliki masyarakat dalam Pencegahan Dan Peningkatan Kualitas Perumahan Kumuh Dan Permukiman Kumuh, karena masyarakat merupakan objek pembangunan sekaligus mitra pemerintah.

Gambar 1.1. Sebagian wilayah kumuh Kota Bontang

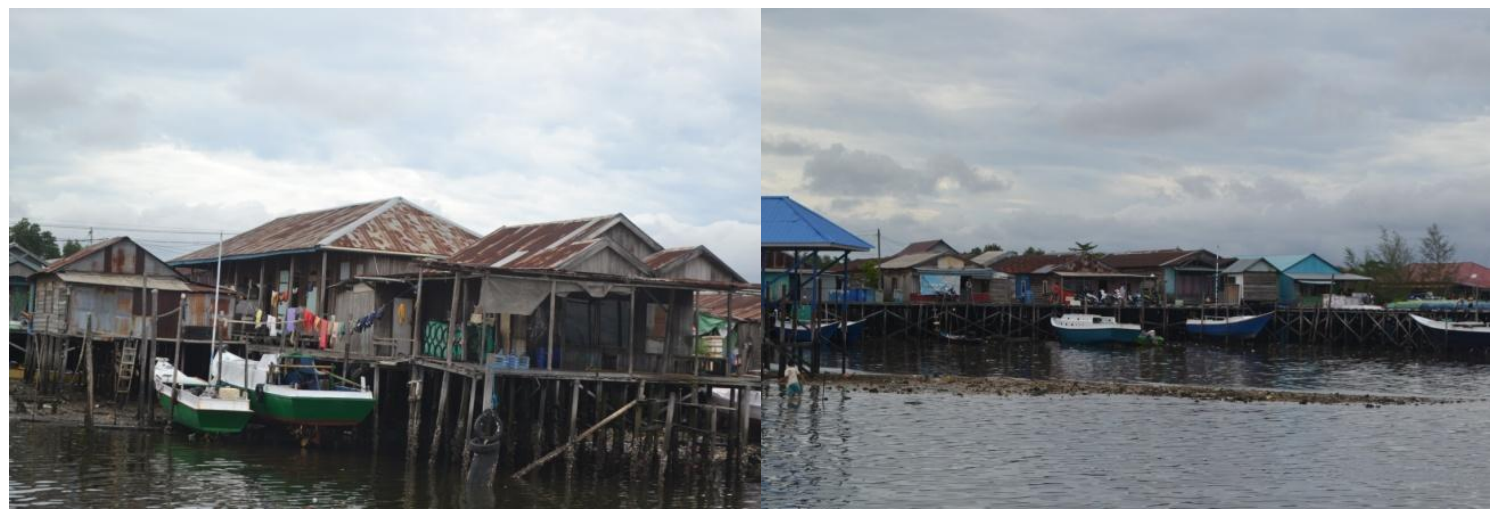

Sumber: Dokumen Tim Pokjanis Raperda Kota Bontang 
Pelibatan Masyarakat sebagai upaya Pemerintah Kota Bontang dalam Pencegahan Dan Peningkatan Kualitas Perumahan Kumuh Dan Permukiman Kumuh bukan hanya sekedar sebuah wacana namun telah benar-benar dilibatkan sebagai sebuah partisipasi aktif semua elemen masyarakat dalam mendukung setiap pembangunan di Kota Bontang, khususnya pada pilot project kota tanpa kumuh sebagai bergaining politik dengan pemerintah pusat.

Upaya tersebut terlihat dari berbagai kegiatan yang melibatkan masyarakat umum, diantaranya Forum Discussion Group (FGD) masyarakat Kota Bontang, serap aspirasi Non Government Organization (NGO) dan pelibatan sejumlah konsultan dan akademisi dalam pembahasan permasalahan kondisi kekumuhan Kota Bontang. Melalui pelibatan masyarakat diharapkan pada 2019 nanti Kota Bontang akan terbebas dari kumuh dengan ditunjang Gerakan 100-0-100 mentargekan penyediaan 100 persen akses aman air minun, nol persen kawasan permukiman kumuh, dan 100 persen akses sanitasi layak, untuk mendukung perwujudan Kota Bontang yang layak huni, produktif, dan berkelanjutan sesuai dengan amanat Undang-undang nomor 1 tahun 2011 tentang penanganan permukiman kumuh wajib dilakukan oleh pemerintah, agar masyarakat berpenghasilan rendah (MBR) memiliki rumah yang layak, bersih dan teratur.

\section{Masalah Penelitian}

Permasalahan yang diangkat dalam penelitian ini berangkat dari kesanggupan Kota Bontang mengemban kepercayaan dari Kementerian Pekerjaan Umum dan Perumahan Rakyat sebagai pelaksana pilot project kota tanpa kumuh.

Tentu saja tidak mudah bagi pihak Pemerintah Kota Bontang dalam melaksanakan kepercayaan tersebut tanpa dukungan dari stakeholders terkait, terutama keterlibatan masyarakat sebagai objek program kota tanpa kumuh pada Kota Kontang. Sehingga permasalahan yang diangkat untuk penelitian ini adalah:

1) Bagaimana upaya Pemerintah Kota Bontang dalam melibatkan masyarakat?

2) Siapa sajakah pihak-pihak masyarakat yang berperan besar dalam pelaksanaan pilot project tersebut?

\section{Tujuan Penelitian}

Adapun yang menjadi tujuan pada penelitian meliputi:

1. Mengetahui dan memahamiupaya Pemerintah Kota Bontang dalam melibatkan masyarakat.

2. Mengenali pihak-pihak masyarakat yang berperan besar dalam pelaksanaan pilot project tersebut.

\section{Fokus Penelitian}

Adapun yang menjadi fokus pada penelitian ini adalah Pelaksanaan Focus Group Discussion (FGD)yang dilaksanakan oleh Tim Konsultan Individu Pendamping Penyusun Rancangan Peraturan Daerah (Raperda) Kota Bontang Tentang Pencegahan Dan Peningkatan Kualitas Terhadap Perumahan Kumuh Dan Permukiman Kumuh Tahun 2016 atas inisiasi Kementerian Pekerjaan Umum Dan Perumahan Rakyat Direktorat Jenderal Cipta Karya Direktorat Pengembangan Kawasan Permukiman bersama Pemerintah Kota Bontang dan DPRD Kota Bontang pada hari Sabtu 4 Juni 2016, bertempat di Balai Pertemuan Umum Kecamatan Bontang Utara Kota Bontang sebagai wujud pelibatan masyarakat dalam pembangunan di Kota Bontang, terutama dalam upaya membebaskan Kota Bontang dari kekumuhan. 


\section{Kerangka Teori}

\subsection{Masyarakat}

Menurut Koentjaraningrat (2011:119) masyarakat merupakan istilah dari bahasa Inggris yakni society (berasal dari bahasa Latin socius yang berarti "kawan). Kata masyarakat berasal dari akar kata Arab syaraka yang artinya "ikut serta, berperanserta".

Lebih dalam, Koentjaraningrat (2011:120) menjelaskan bahwa masyarakat adalah sekumpulan manusia yang saling berinteraksi. Diperkuat oleh Sarman (2005:107) bahwa masyarakat yang baik adalah masyarakat yang beradab yakni masyarakat yang menjaga kepatutan sosial atau dengan kata lain sebagai uapaya menenggang rasa orang lain.

\subsection{Partisipasi sebagai Model Pelibatan Masyarakat}

Menurut Mikkelsen (2005:54) dalam Adi (2008:108) bahwa partisipasi merupakan kegiatan yang berasal dari masyarakat dan dikelola oleh masyarakat itu sendiri, partisipasi adalah tujuan dalam suatu proses demokrasi.

Sedangkan menurut Adi (2008: 111) bahwa partisipasi masyarakat adalah keikutsertaan masyarakat dalam proses pengidentifikasian masalah dan potensi yang ada dimasyarakat, pemilihan dan pengambilan keputusan tentang alternatif solusi untuk menangani masalah, pelaksanaan upaya mengatasi masalah, dan keterlibatan masyarakat dalam proses mengevaluasi perubahan yang terjadi.

\subsection{Pemerintah Kota Bontang}

Pemerintah Kota Bontang merupakan bentuk dari pemerintah daerah, mangacu pada Undang-Undang Republik Indonesia Nomor 23 Tahun 2014 Tentang Pemerintahan Daerah pasal 1 nomor 3 bahwa Pemerintah Daerah adalah kepala daerah sebagai unsur penyelenggara Pemerintahan Daerah yang memimpin pelaksanaan urusan pemerintahan yang menjadi kewenangan daerah otonom.

Dengan demikian, maka Pemerintah Kota Bontang adalah kepala daerah yakni pada Kota Bontang sebagai unsur penyelenggara pemerintahan di Kota Bontang yang memimpin pelaksanaan urusan pemerintahan yang menjadi kewenangan daerah otonom sesuai peraturan perundang-undangan yang berlaku di Indonesia.

\subsection{Pencegahan Dan Peningkatan Kualitas Perumahan Kumuh Dan Permukiman Kumuh}

\subsubsection{Rumah}

Menurut Peraturan Menteri Pekerjaan Umum dan Perumahan Rakyat Nomor 2 Tahun 2016 tentang Peningkatan Kualitas Perumahan Kumuh dan Permukiman Kumuh, Rumah adalah bangunan gedung yang berfungsi sebagai tempat tinggal yang laik huni, sarana pembinaan keluarga, cerminan harkat dan martabat penghuninya, serta aset bagi pemiliknya.

Definisi lain dari Azwar (1996) dan Mukono (2000) dalam Akbar (2015;1) bahwa rumah adalah tempat untuk melepas lelah, tempat bergaul, dan membina rasa kekeluargaan diantara anggota keluarga, tempat berlindung keluarga dan menyimpan barang berharga, dan rumah juga sebagai status lambang sosial.

\subsubsection{Perumahan}


Menurut Azwar (1996) dan Mukono (2000) dalam Akbar (2015;1) bahwa perumahan adalah kelompok rumah yang berfungsi sebagai lingkungan tempat tinggal atau hunian yang dilengkapi dengan prasarana lingungan yaitu kelengkapan dasar fisik lingkungan, misalnya penyediaan air minum,pembuangan sampah, tersedianya listrik, telepon, jalan, yang memungkinkan lingkungan pemukiman berfungsi sebagaimana mestinya.

Menurut Peraturan Menteri Pekerjaan Umum dan Perumahan Rakyat Nomor 2 Tahun 2016 tentang Peningkatan Kualitas Perumahan Kumuh dan Permukiman Kumuh, Perumahan adalah kumpulan rumah sebagai bagian dari permukiman, baik perkotaan maupun perdesaan, yang dilengkapi dengan prasarana, sarana, dan utilitas umum sebagai hasil upaya pemenuhan rumah yang laik huni.

\subsubsection{Permukiman}

Menurut Peraturan Menteri Pekerjaan Umum dan Perumahan Rakyat Nomor 2 Tahun 2016 tentang Peningkatan Kualitas Perumahan Kumuh dan Permukiman Kumuh, Permukiman adalah bagian dari lingkungan hunian yang terdiri atas lebih dari satu satuan perumahan yang mempunyai prasarana, sarana, utilitas umum, serta mempunyai penunjang kegiatan fungsi lain di kawasan perkotaan atau kawasan perdesaan.

\subsubsection{Perumahan Kumuh}

Menurut Puspitasari (2015:1) Perumahan kumuh adalah kawasan di mana rumah dan kondisi hunian masyarakat di kawasan tersebut sangat buruk. Rumah maupun sarana dan prasarana yang ada tidak sesuai dengan standar yang berlaku, baik standar kebutuhan, kepadatan bangunan, persyaratan rumah sehat, kebutuhan sarana air bersih, sanitasi maupun persyaratan kelengkapan prasarana jalan, ruang terbuka, serta kelengkapan fasilitas sosial lainnya.

Menurut Peraturan Menteri Pekerjaan Umum dan Perumahan Rakyat Nomor 2 Tahun 2016 tentang Peningkatan Kualitas Perumahan Kumuh dan Permukiman Kumuh, Perumahan Kumuh adalah perumahan yang mengalami penurunan kualitas fungsi sebagai tempat hunian.

\section{Gambar 5.1. Ilustrasi}

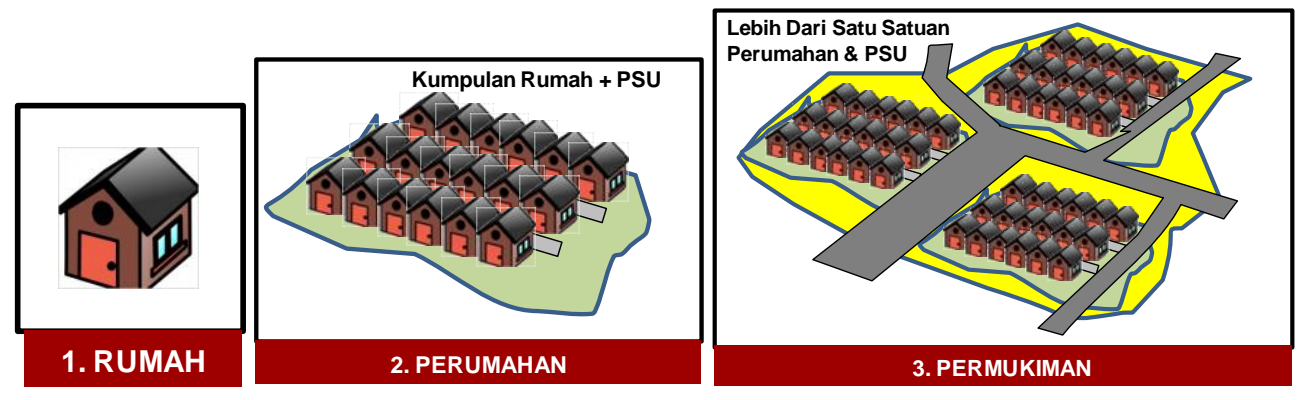

\subsubsection{Permukiman atau Kawasan Kumuh}

Menurut Peraturan Menteri Pekerjaan Umum dan Perumahan Rakyat Nomor 2 Tahun 2016 tentang Peningkatan Kualitas Perumahan Kumuh dan Permukiman Kumuh, Permukiman Kumuh adalah permukiman yang tidak laik huni karena ketidakteraturan bangunan, tingkat kepadatan bangunan yang tinggi, dan kualitas bangunan serta sarana dan prasarana yang tidak memenuhi syarat. 
Pendapat lain diberikan oleh Fircska (2009) yang menjelaskan bahwa Permukiman kumuh (slum) merupakan kawasan kota berkepadatan penduduk tinggi dan memiliki karakteristik permukiman dibawah standar kelayakan. Karakteristik dasar dari permukiman kumuh yaitu berkepadatan tinggi dan kondisi perumahan dibawah standar (fisik serta sarana dan prasarana).

\subsubsection{Kualitas}

Menurut ISO-8402 (Loh, 2001:35)dalam Kurniawan (2015:1), Kualitas adalah totalitas fasilitas dan karakteristik dari produk atau jasa yang memenuhi kebutuhan, tersurat maupun tersirat. Sedangkan menurut Tjiptono (2004:11)dalam Kurniawan (2015:1), Mendefinisikan kualitas sebagai kesesuaian untuk digunakan.

\subsubsection{Peningkatan Kualitas Terhadap Perumahan Kumuh Dan Permukiman Kumuh}

Menurut Peraturan Menteri Pekerjaan Umum dan Perumahan Rakyat Nomor 2 Tahun 2016 tentang Peningkatan Kualitas Perumahan Kumuh dan Permukiman Kumuh, Peningkatan Kualitas Terhadap Perumahan Kumuh Dan Permukiman Kumuh adalah upaya untuk meningkatkan kualitas bangunan, serta prasarana, sarana dan utilitas umum.

\section{Metode Penelitian}

\subsection{Jenis dan pendekatan Penelitian}

Berdasarkan pertanyaan dan tujuan penelitian, maka jenis penelitian ini adalah penelitian kualitatif dengan pendekatan deskriptif atau bersifat "menggambarkan" upaya yang dilakukan Pemerintah Kota Bontang dalam melibatkan masyarakat untuk melakukan Pencegahan Dan Peningkatan Kualitas Perumahan Kumuh Dan Permukiman Kumuh tahun 2016.

\subsection{Teknik Analisis Data}

Analisis menggunakan model analisis interaktif teori Miles dan Huberman (1994), yakni reduksi data, tampilan data, kesimpulan: gambaran dan verifikasi.

\section{Profil Kota Bontang}

\subsection{Visi dan Misi}

Mengacu pada Peraturan Daerah Kota Bontang Nomor 5 Tahun 2011 tentang RPJPD Kota Bontang Tahun 2005 - 2025, maka disebutkan Visi dan Misi Kota Bontang sebagai berikut :

Visi : "Menguatkan Bontang Sebagai Kota Maritim, Berkebudayaan Industri Yang Bertumpu Pada Kualitas SDM Dan Lingkungan Hidup Untuk Kesejahteraan Masyarakat".

Misi :

1. Menjadikan Kota Bontang sebagai Smart City melalui peningkatan kualitas SDM

2. Menjadikan Kota Bontang sebagai Green City melalui peningkatan kualitas lingkungan hidup

3. Menjadikan Kota Bontang sebagai Creative City melalui kegiatan pengembangan perekonomian berbasis sektor maritim. 


\subsection{Perumahan dan Permukiman Kumuh}

Keterkaitan dengan sektor perumahan dan kawasan permukiman, maka Misi Ke-2, menunjukkan pembangunan aspek perumahan dan kawasan permukiman. Pada misi Ke-2 tersebut terdapat 3 isu penting yang difokuskan pada arahan RPJPD Kota Bontang Tahun 2005 - 2025, yaitu Penataan Ruang, Perumahan dan Permukiman, serta Lingkungan Hidup. Kebijakan dan strategi pencapaian pada misi Ke-3 tersebut adalah sebagai berikut :

Strategi 1 : Pembangunan perumahan dan permukiman yang berwawasan lingkungan

\section{Arah kebijakan :}

a. Pembinaan dan peningkatan kualitas lingkungan perumahan dan permukiman disertai dengan penyediaan infrastruktur dasar yang memadai

b. Pemenuhan kebutuhan perumahan dan permukiman sesuai tingkat kemampuan pendapatan masyarakat

c. Penataan dan revitalisasi kawasan permukiman kumuh

d. Penataan dan pembatasan permukiman di atas air dalam rangka perlingungan ekosistem pesisir dan green belt

Strategi 2 : Air bersih

\section{Arah kebijakan :}

a. Penyediaan drainase kota, embung, daerah resapan dan ruang terbuka hijau yang mampu mengurangi genangan air dan mencegah terjadinya banjir

b. Penyediaan air bersih yang memenuhi syarat dengan cakupan layanan mendekati $90 \%$ oleh pemerintah.

\subsection{Letak dan Luas Wilayah}

Kota Bontang merupakan daerah otonom yang secara geografis berada pada posisi antara $117^{0} 23^{\prime}-117^{0} 38^{\prime} \mathrm{BT}$ dan $0^{0} 01^{\prime}-0^{0} 14^{\prime} \mathrm{LU}$ dengan ketinggian antara 0 - $160 \mathrm{~m}$ diatas permukaan laut. Terletak pada jalur poros jalan Trans-Kalimantan dan menghadap jalur Selat Makasar, Kota Bontang memiliki pelabuhan khusus milik PT. Pupuk Kalimantan Timur (PKT) dan PT. Badak NGL yang dapat dikunjungi kapal dari seluruh penjuru dunia serta dua pelabuhan umum yang berada di Lok Tuan dan Tanjung Laut. Sarana pelabuhan dan posisi yang strategis tersebut merupakan potensi yang sangat menguntungkan bagi berkembangnya interaksi Kota Bontang dengan wilayah sekitarnya, baik dalam skala nasional, regional maupun internasional.

Secara administratif wilayah Kota Bontang terletak dibagian tengah wilayah Kalimantan Timur, berada pada pesisir pantai timur dengan posisi batas wilayah sebagai berikut:

- Sebelah Utara $\quad$ : Kecamatan Sangatta Kabupaten Kutai Timur,

- Sebelah Selatan : Kecamatan Marangkayu Kabupaten Kutai Kertanegara,

- Sebelah Barat : Kecamatan Sangatta Kabupaten Kutai Timur,

- Sebelah Timur : : Selat Makasar.

Wilayah Kota Bontang memiliki luas keseluruhan 497,57 $\mathrm{km}^{2}$ yang diidominasi oleh lautan, memiliki wilayah daratan seluas $147,8 \mathrm{~km}^{2}(29,70 \%)$, yang terdiri dan atas: 
- Kawasan Hutan Lindung/TNK

- PT. Badak NGL, Co

- PT. Pupuk Kaltim

- Areal Efektif untuk Pembangunan
: $5.950 \mathrm{Ha}(11,96 \%)$,

: $1.572 \mathrm{Ha}(3,15 \%)$,

: $2.010 \mathrm{Ha}(4,04 \%)$,

: 5,248 Ha $(10,56 \%)$;

Pada awalnya Kota Bontang merupakan kota administratif sebagai bagian dari Kabupaten Kutai dan menjadi Daerah Otonom berdasarkan Undang- Undang No. 47 Tahun 1999 tentang pemekaran Provinsi dan Kabupaten, bersama- sama dengan Kabupaten Kutai Timur dan Kabupaten Kutai Kertanegara.

Sejak disahkannya Peraturan Daerah Kota Bontang No. 17 tahun 2002 tentang Pembentukan Organisasi Kecamatan Bontang pada tanggal 16 Agustus 2002, Kota Bontang terbagi menjadi 3 kecamatan, yaitu Kecamatan Bontang Selatan, Kecamatan Bontang Utara, dan Kecamatan Bontang Barat.

Kecamatan Bontang Selatan memiliki wilayah daratan paling luas $\left(104,40 \mathrm{~km}^{2}\right)$, disusul Kecamatan Bontang Utara $\left(26,20 \mathrm{~km}^{2}\right)$ dan Kecamatan Bontang Barat $\left(17,20 \mathrm{~km}^{2}\right)$.

Tabel 7.1. Letak Geografis dan Luas Wilayah Daratan per Kecamatan

\begin{tabular}{|l|c|c|c|}
\hline \multicolumn{1}{|c|}{ Kecamatan } & Bujur Timur & Lintang Utara & Luas $\left(\mathbf{k m}^{2}\right)$ \\
\hline Bontang Selatan & $117^{\circ} 23^{\prime}-117^{\circ} 38^{\prime}$ & $0^{\circ} 01^{\prime}-0^{\circ} 08^{\prime}$ & 104,40 \\
\hline Bontang Utara & $117^{0} 28^{\prime}-117^{0} 38^{\prime}$ & $0^{\circ} 07^{\prime}-0^{\circ} 12^{\prime}$ & 26,20 \\
\hline Bontang Barat & $117^{\circ} 24^{\prime}-117^{0} 28^{\prime}$ & $0^{\circ} 06^{\prime}-0^{\circ} 10^{\prime}$ & 17,20 \\
\hline
\end{tabular}

Sumber : Dinas Pertanahan Kota Bontang, 2007

Nama, jumlah Kelurahan dan RT pada masing-masing Kecamatan di Kota Bontang sebagai berikut:

a) Kecamatan Bontang Utara:

Kelurahan Bontang Baru (28 RT),Kelurahan Bontang Kuala (13 RT),Kelurahan Lok Tuan (51 RT),Kelurahan Guntung (24 RT),Kelurahan Gunung Elai (41 RT),Kelurahan Api - Api (37 RT).

b) Kecamatan Bontang Selatan:

Kelurahan Berebas Pantai (24 RT),Kelurahan Berebas Tengah (62 RT),Kelurahan Satimpo (25 RT),Kelurahan Tanjung Laut (38 RT),Kelurahan Tanjung Laut Indah (33 RT),Kelurahan Bontang Lestari (18 RT).

c) Kecamatan Bontang Barat:

Kelurahan Gunung Telihan (30 RT),Kelurahan Kanaan (12 RT),Kelurahan Belimbing (51 RT).

\subsection{Demografis}

Pada dasarnya Kota Bontang memiliki wilayah yang paling kecil dibandingkan wilayah Kabupaten/Kota lain di Provinsi Kalimantan Timur. Begitupun jumlah penduduk yang hanya berjumlah 155.880 jiwa pada tahun 2013 dan meningkat menjadi 159.614 ditahun 2014 atau naik 2,39\% atau dapat dikatakan memiliki laju pertumbuhan penduduk relatif tinggi (BPS Kota Bontang 2015). 
Pertumbuhan tersebut diiringi dengan semakin beragamnya jenis aktifitas masyarakat. Sehingga menyebabkantingkat taraf kehidupan masyarakat terus mengalami penurunan kualitas baik tingkat lingkungan dan pendapatan serta tumbuhnya permukiman kumuh (Dinas Tata Ruang Kota Bontang, 2011:1).

\subsection{Pekerjaan}

Berdasarkan status pekerjaan, tenaga kerja Kota Bontang terkini menurut BPS Kota Bontang tahun 2015 didominasi oleh buruh, karyawan, dan pegawai yakni 56,42\% baik laki-laki maupun wanita. Untuk jenis pekerjaan di Kota Bontang yakni sektor jasa yang terdiri dari administrasi pemerintahan, pertahanan, pendidikan, kesehatan, dan jasa sosial kemasyarakatan.

\subsection{Status Hak Huni}

Menurut data BPS Kota Bontang tahun 2015, berdasarkan status hak huni terdapat 3 (tiga) kategori yakni hak milik, sewa, dan lainnya berupa bebes sewa atau rumah dinas, sebagaimana Tabel berikut:

Tabel 7.3. Persentase Rumah Tangga Menurut Status Kepemilikan Rumah di Kota Bontang tahun 2014.

\begin{tabular}{|l|l|l|l|}
\hline Status Kepemilikan Rumah & $\mathbf{2 0 1 2}$ & $\mathbf{2 0 1 3}$ & $\mathbf{2 0 1 4}$ \\
\hline Milik sendiri & 62,59 & 61,08 & 56,09 \\
\hline Kontrak/sewa & 25,94 & 30,36 & 27,87 \\
\hline Lainnya & 11,46 & 8,56 & 16,04 \\
\hline Jumlah & 100,00 & 100,00 & 100,00 \\
\hline
\end{tabular}

Sumber : Kota Bontang Dalam Angka, 2015

Berdasarkan Tabel 4.2. tersebut menunjukkan bahwa sebagian besar rumah tangga di Kota Bontang menempati rumah dengan status milik sendiri, dan ini mengindikasikan tingkat kesejahteraan masyarakat, meskipun tidak selalu mutlak. Tingginya angka migrasi masuk ke Kota Bontang memicu perkembangan usaha rumah sewa dengan jumlah 27,87\%, ditambah dengan $16,04 \%$ masyarakat yang menempati status rumah lainnya baik bebas sewa dan rumah dinas.

\subsection{Kondisi Kawasan Permukiman}

7.7.1. Komponen Pemanfaatan Ruang Permukiman Kawasan permukiman di Kota Bontang terdiri dari komponen-komponen pemanfaatan ruang sebagai berikut : 


\section{Pemerintah Kota Bontang dan Upaya Pencegahan Dan Peningkatan Kualitas Perumahan Kumuh Dan Permukiman Kumuh}

Sebagai upaya dalam pencegahan dan peningkatan kualitas perumahan kumuh dan permukiman kumuh, Pemerintah Kota Bontang memperkuat gerakan 100-0-100 bersama 2 (dua) tim dari Kementerian Pekerjaan Umum Dan Perumahan Rakyat (PUPR) Direktorat Jenderal Cipta Karya Direktorat Pengembangan Kawasan Permukiman, yakni:

1) Tim Program KOTAKU untuk Bontang, dan

2) Tim Konsultan Individu Pendamping Penyusun Rancangan Peraturan Daerah (Raperda) Kota Bontang Tentang Pencegahan Dan Peningkatan Kualitas Terhadap Perumahan Kumuh Dan Permukiman Kumuh Tahun 2016.

\section{Gambar 8.1. Kegiatan FGD}

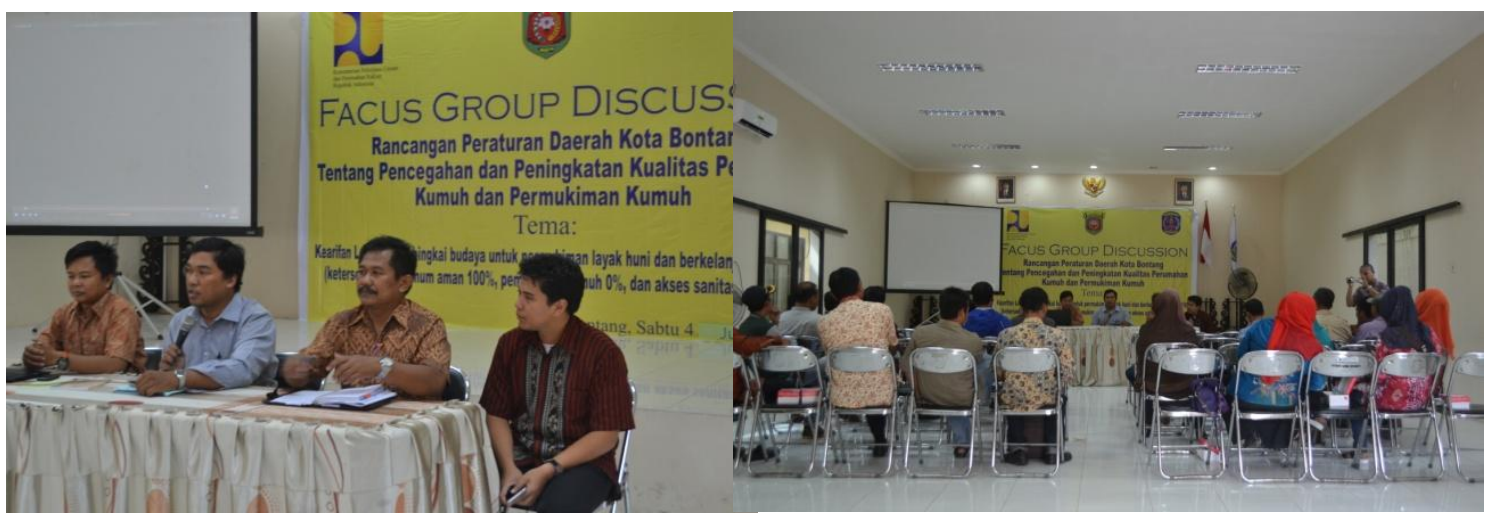

Sumber: Dokumen Bappeda Kota Bontang

Secara praktis, kedua tim tersebut memiliki tanggung jawab yang berbeda, namun keduanya dalam melaksanakan tugas saling mendukung dan tentu saja langsung berhubungan dengan masyarakat, baik dengan melalui Bappeda Kota Bontang atau mandiri.

Namun, sebagaimana fokus penelitian maka peneliti lebih menitikberatkan pada kegiatan FGD yang dilaksanakan oleh Tim Konsultan Individu Pendamping Penyusun Rancangan Peraturan Daerah (Raperda) Kota Bontang yang berasal dari para akademisi dibidang (1) Permukiman, (2) Sosial, dan (3) Hukum.

\subsection{Upaya Pemerintah Kota Bontang dalam melibatkan masyarakat.}

Berdasarkan informasi yang peneliti peroleh dari ketiga Tim Konsultan Individu bahwa pelaksanaan FGD bersama perwakilan warga dari Kecamatan dan sejumlah Kelurahan yang hadir telah melalui koordinasi dengan Bappeda Kota Bontang bersama Tim Pokjanis Perumus RancanganPeraturan Daerah (Raperda) Kota Bontang TentangPencegahan Dan PeningkatanKualitasTerhadapPerumahanKumuh Dan PermukimanKumuhTahun 2016, dan difasilitasi oleh pihak Kecamatan Bontang Utara sebagai tuan rumah pelaksanaan FGD.

Melalui Bappeda Kota Bontang yang sudah terbiasa melaksanakan FGD bersama Tim Program KOTAKU, antusiasme peserta dari berbagai latar belakang masyarakat memberikan sejumlah aspirasi yang sangat bermanfaat dalam penyusunan RancanganPeraturan Daerah (Raperda) tersebut, terutama dalam memperkaya poin-poin penting yang berhubungan dengan local whisdom atau ke-khas-an Kota Bontang sebagai penciri dan pembeda dari Peraturan Daerah serupa dari 269 daerah pilot project lain yang ada di Indonesia. 
8.2. Pihak-pihak masyarakat yang berperan besar dalam pelaksanaan pilot project tersebut.

Menyaksikan proses dan sukses pelaksanaan FGD yang dipandu oleh Tim Konsultan Individu diketahui bahwa terdapat sejumlah elemen masyarakat yang memiliki peran besar, diantaranya dari pihak tokoh masyarakat, tokoh agama, tokoh pemuda, akademisi, lembaga dan kelompok swadaya masyarakat, ibu-ibu PKK, dan tentu dari Tim Program KOTAKU Kota Bontang.

Adapun maasukan masyarakat pada FGD menjelaskan bahwa secara umum permasalahan kekumuhan di Kota Bontang berkenaan dengan:

1) Supremasi produk hukum yang masih lemah dan kurang implementatif, pelayanan infrastruktur permukiman yang masih belum optimal, permasalahan perilaku hidup sehat dari masyarakat yang masih sangat kurang baik dan kurang sehat.

2) Masyarakat Kota Bontang mendukung upaya-upaya Penyusunan Rancangan Peraturan Daerah (Raperda) tentang Pencegahan dan Peningkatan Kualitas Perumahan Kumuh dan Permukiman Kumuh di Kota Bontang.

Sedangkan secarakhusussebagai penekananmuatanlokalpada:

1) Pengenaansanksi-sanksiterhadappelanggaranregulasi.

2) Pemberianizinmendirikanbangunankhususnyapadaaspek proses danmekanismepemberianizin.

3) Tipologikawasankumuhharusdisesuaikanpadakondisieksisting yang didominasipermukimandanperumahan di atas air dan di tepi air serta di daratan.

4) Penetapanlokasiperumahandankawasanpermukimankumuhjugaharusdidasarkanpadakondi sieksisting.

5) Aspekpenyediaantanah agar dapatdiberikansosialisasidanpendampinganterkaittatacaradanmekanismepenyediaantanah untukkepentinganumumserta proses danperhitungangantirugitanah.

6) Aspekpenyediaaninfrastrukturpermukimanseperti air bersih, sanitasi, dan lain sebagainyadisesuaikandengankondisieksisting.

7) Perlu penguatan dukungan pihak swasta dalah hal ini korporasi yang beroperasional di Kota Bontang melalui (salah satunya) program Corporate Social Responsibility (CSR), sehingga keterbatasan kemampuan pihak Pemerintah Kota dapat teratasi baik dari pendanaan atau pemberdayaan, ditambah dengan penguatan kesadaran masyarakat sendiri.

\section{Analisa dan Pembahasan}

Berdasarkan Poin 8 mengenai Upaya Pemerintah Kota Bontang dalam Pencegahan Dan Peningkatan Kualitas Perumahan Kumuh Dan Permukiman Kumuh, maka informasi tersebut perlu dianalisa dengan sejumlah teori sebagaimana telah diuraikan pada poin 5.

9.1. Upaya Pemerintah Kota Bontang dalam melibatkan masyarakat.

Pelibatan Masyarakat sebagai upaya $P$ emerintah Kota Bontang dalam $P$ encegahan

Dan Peningkatan Kualitas Perumahan Kumuh Dan Permukiman Kumuh $>>12$ 
Mencermati poin 8.1. diatas, maka dapat dipahami bahwa Pemerintah Kota Bontang telah bersungguh-sungguh dalam mengakomodir aspirasi semua pihak terutama berbagai elemen dimasyarakat Kota bontang melalui FGD yang dipandu oleh Tim Konsultan Individu. Selain masyarakat umum, pihak Pemerintah Kota Bontang juga mempersilahkan pelibatan Tim Program KOTAKU Kota Bontang dalam memberikan aspirasi.

Dengan demikian, perwujudan program Kota Tanpa Kumuh di Kota Bontang telah menjadi bagian dan tanggung jawab masyarakat Kota Bontang secara menyeluruh melalui partisipasi yang mendalam dan integratif, sehingga masyarakat siap mengawal implementasi dan penegakan Peraturan Daerah Kota Bontang TentangPencegahan Dan PeningkatanKualitasTerhadapPerumahanKumuh Dan PermukimanKumuhTahun 2016 dengan penuh kesadaran.

Hal tersebut merupakan esensi dari konsep partisipasi sebagaimana yang disampaikan oleh Mikkelsen dan Adi pada poin 5.2 diatas. Kondisi tersebut karena adanya rasa memiliki dan bangga atas local whisdomatau kearifan lokal yang mereka miliki sebagai ke-khas-an peraturan daerah tersebut nanti kedepan.

9.2. Pihak-pihak masyarakat yang berperan besar dalam pelaksanaan pilot project tersebut.

Berdasarkan poin 8.2 diatas, dapat diketahui bahwa terdapat sejumlah unsur kemasyarakatan di Kota Bontang yang telah berpartisipasi aktif dan berperan besar dalam memperkaya program dan mendukung proses pencegahan dan peningkatan kualitas perumahan kumuh dan permukiman kumuh di Kota Bontang.

Kondisi tersebut terbukti dengan adanya masukan yang bersifat umum dan khusus yang menjadi catatan pengayaan isi rancangan peraturan daerah tentang pencegahan dan peningkatan kualitas perumahan kumuh dan permukiman kumuh Kota Bontang yang masuk pada agenda pembahasan Tim Pokjanis Raperda pada kegiatan lanjutan yakni pra konsensus di ruang rapat utama Bappeda Kota Bontang.

Masukan yang bersifat membangun, bukan hanya dilihat dari kekuatan isi masukan tetapi juga dari banyaknya pihak-pihak dan unsur masyarakat yang hadir sebagaimana yang disebutkan pada alinea pertama poin 8.2 diatas, ditambah pengalaman yang diperoleh dari Tim Program KOTAKU Kota Bontang dalam memberikan metode FGD yang konstruktif.

Poin 8.2 angka 7 bahwa menurut beberapa tokoh masyarakat dan lembaga atau kelompok swadaya masyarakat perlu ada pelibatan dan penguatan dukungan pihak swasta ataupun korporasi BUMN yang beroperasional di Kota Bontang melalui (salah satunya) program Corporate Social Responsibility (CSR), sehingga keterbatasan kemampuan pihak Pemerintah Kota dapat teratasi baik dari pendanaan atau pemberdayaan, ditambah dengan penguatan kesadaran masyarakat sendiri. Mengingat selama ini ada beberapa wilayah sekitaran dari PT. Pupuk Kaltim yang membantu pemenuhan atau ketersediaan air bersih bagi masyarakat.

\section{Temuan Hasil Penelitian}

Berdasarkan poin 8 dan 9 diatas, dapat dipahami bahwa Pemerintah Kota Bontang selain perlu dukungan dari pihak masyarakat Kota Bontang juga memerlukan partisipasi dari pihak swasta ataupun korporasi dari BUMN yang beroperasi di wilayah Kota Bontang, seperti PT. Pupuk Kaltim, PT. Badak LNG, dan korporasi lain.

Untuk itu, perlu dilakukan penelitian pengembangan terutama yang berkenaan dengan pelibatan dan penguatan dukungan pihak swasta ataupun korporasi dari BUMN dalam 
Pencegahan Dan Peningkatan Kualitas Perumahan Kumuh Dan Permukiman Kumuh di Kota Bontang.

\section{Simpulan}

Berdasarkan hasil penelitian hasil penelitian "Pelibatan Masyarakat sebagai upaya Pemerintah Kota Bontang dalam Pencegahan Dan Peningkatan Kualitas Perumahan Kumuh Dan Permukiman Kumuh" dapat disimpulkan bahwa:

1) Perwujudan program Kota Tanpa Kumuh di Kota Bontang telah menjadi bagian dan tanggung jawab masyarakat Kota Bontang secara menyeluruh melalui partisipasi yang mendalam dan integratif.

2) Terdapat sejumlah pihak dan elemen masyarakat yang memiliki peran besar, diantaranya dari pihak tokoh masyarakat, tokoh agama, tokoh pemuda, akademisi, lembaga dan kelompok swadaya masyarakat, ibu-ibu PKK, dan tentu dari Tim Program KOTAKU Kota Bontang yang telah memberi pengayaan Rancangan Peraturan Daerah Kota Bontang tentang Pencegahan Dan Peningkatan Kualitas Perumahan Kumuh Dan Permukiman Kumuh.*****

\section{Referensi}

\section{Buku:}

Adi, Isbandi Rukminto. 2008. Intervensi komunitas: pengembangan masyarakat sebagai upaya pemberddayaan masyarakat. Jakarta: PT. Rajagrafindo Persada.

Alston, Margaret., \& Wendy Bowles. (2003). Research for social workers: and introduction to methods ( $2^{\text {nd }}$ ed.). Canberra: Allen \& Unwin.

Denzim, Norman K., Yvonna S. Lincoln. (2009). Handbook of qualitative research (Dariatno dkk, Penerjemah). Yogyakarta: Pustaka Pelajar.

Fathoni, Abdurrahmat. 2006. Antropologi sosial budaya: suatu pengantar. Jakarta: PT Rineka Cipta.

Fircska, Szcilard. 2009. Land and Slum Upgrading. UN Habitat Working Paper 10. Nairobi: UN Habitat.

Irawan, Prasetya. (2006). Penelitian kualitaif \& kuantitatif untuk ilmu-ilmu sosial. Depok: Departemen Ilmu Administrasi FISIP UI.

Kontjaraningrat. 2011. Pengantar Antropologi I. Jakarta: PT Rineka Cipta.

Miles, Matthew B., \& A. Michael Huberman. (1994). Qualitative data analyses (second edition). London: SAGE Publications.

Moleong, Lexy J. (2010). Metodologi penelitian kualitatif (Ed. Revisi). Bandung: PT. Remaja Rosdakarya.

Ndraha, Taliziduhu. (2010). Metodologi ilmu pemerintahan. Jakarta: Rineka Cipta.

Neuman, W. Lawrence. (2006). Social Research Methods: Qualitatative and Quantitative Approaches. (4 th ed). USA: Allyn and Bacon.

Ogden, Russel. (2008). "Informant”. Ed. Given, Lisa M. The sage encyclopedia of qualitative research methods volumes $1 \& 2$. UK: London, SAGE Publications, Inc. 430-431. 
Raco, J.R. (2010). Metode penelitian kualitatif: jenis, karakteristik dan keunggulannya. Jakarta: PT. Gramedia Widiasarana Indonesia.

Rustiadi, Ernan., Sunsun Saefulhakim, Dyah R. Panuju. 2009. Perencanaan dan pengembangan wilayah. Jakarta: Crestpent press dan Yayasan Obor Indonesia.

Sarman, Mukhtar. 2005. Selayang pandang sistem sosiokultural Indonesia. Banjarmasin: Pustaka Banua.

Schensul, Jean J. (2008). "Methodology". Ed. Given, Lisa M. The sage encyclopedia of qualitative research methods volumes $1 \& 2$. UK: London, SAGE Publications, Inc. 516521.

Strauss, Anselm L. (1987).Qualitative analysis for social scientists. UK:Cambridge University Press.

Sugiyono.(2005). Memahami Penelitian Kualitatif, Bandung: Alfabetha

Sugiono. (2010). Metode penelitian kuantitatif, kualitatif dan R\&D. Bandung: Alfabeta

Vanderstoep, Scott W., \& Dierdre D. Johnston. (2009). Research methods for everyday life: blending qualitative and quantitative approaches. CA: San Fransisco. John Wiley \& Sons, Inc.

Walliman, Nicholas. (2006). Social Research Methods. UK: London SAGE Publications

\section{Peraturan Perundang-undangan}

Undang-Undang Republik Indonesia Nomor 23 Tahun 2014 Tentang Pemerintahan Daerah

Undang-Undang Republik Indonesia Nomor 9 Tahun 2015 Tentang Perubahan Kedua Atas Undang-Undang Nomor 23 Tahun 2014 Tentang Pemerintahan Daerah.

Undang-Undang Republik Indonesia Nomor 1 Tahun 2011 TentangPenanganan Permukiman Kumuh

Peraturan Menteri Pekerjaan Umum dan Perumahan Rakyat Nomor 2 Tahun 2016 tentang Peningkatan Kualitas Perumahan Kumuh dan Permukiman Kumuh

\section{Dokumen Pemerintah}

BPS Kota Bontang. Kota Bontang Dalam Angka, 2010.

Keputusan Walikota Bontang Nomor 106 Tahun 2015 Tentang Penetapan Lokasi Permukiman Kumuh Kota Bontang

Pemerintah Kota Bontang. Dinas Tata Ruang Kota Bontang. Identifikasi Kawasan Kumuh Kota Bontang. 2011.

\section{Makalah Online}

Akbar, Mufti. 2015. Definisi perumahan dan rumah. https://www.scribd.com/doc/119759658/DefinisiPerumahan-Dan-Rumah

Kurniawan, Aris. (2015). 5 Pengertian Kualitas Menurut Para Ahli. http://www.gurupendidikan.com/ 5-pengertian-kualitas-menurut-para-ahli/ 
Puspitasari, Diana. 2015. Permukiman Kumuh. Dinas Tata Ruang dan Permukiman (Distarkim)

Kota Depok. http://jakartapedia.bpadjakarta.net/index.php/Permukiman_Kumuh

$* * * * *$ 